\title{
Livelihood Transformations of the Orang Rimba as Tacit Resistance in the Context of Deforestation ${ }^{1}$
}

\author{
Adi Prasetijo \\ Program Studi Antropologi, Fakultas Ilmu Budaya \\ Universitas Diponegoro Semarang \\ Email: prasetijo@gmail.com
}

\begin{abstract}
The Orang Rimba are one of the hunter-gatherer groups remaining in Sumatra. Their livelihoods are based on managing the forest in which they live. They follow the tradition of natural resource management that is based on non-wood forest products $(\varnothing$. Sandbukt, 1988). State policies that focus on economic development since the New Order regime have ultimately affected their lives. Many forest areas and the territories in which they practice nomadism are being converted into plantations, agricultural land, and residential development, which all contribute to the condition of deforestation. State policy also does not favor the Indigenous people. If we look at spatial development in Jambi over the past 25 years, the allocation of land for other uses, such as residences, estates, and physical development, has shown little regard for the indigenous people who live in the forest region. Orang Rimba have no area left in which to roam and continue their lives as traditional hunters and gatherers. Cut off from their cultural roots, they cannot any longer live in accordance with their culture and tradition. As a group, they suffer both physical and socio-cultural displacement. Orang Rimba react to this situation in different ways to transform their livelihoods into a survival mode in order to face the everyday reality of accelerated deforestation. Under these new circumstances, Orang Rimba livelihoods can be regarded as 'tacit resistance' or, to use James Scott's term, a 'hidden transcript' of the weapons of the weak(Scott, 1985). They use a variety of ways to make a living, both economic and sociocultural. NGOs also have a prominent role to support the Orang Rimba. NGOs assist the Orang Rimba to put themselves in a position parallel to other communities. This paper will look at the impact of Jambi spatial policies that have been unfavorable to Indigenous People and how the Orang Rimba respond to them.
\end{abstract}

Keywords: Livelihood, Resistance, Survival, Deforestation, Orang Rimba

\footnotetext{
${ }^{1}$ This paper was presented at $6^{\text {th }}$ International Symposium of Journal Anthropology Indonesia, University of Indonesia, 26-28 July 2016, Jakarta Indonesia. I want to thanks to Prof. Greg Acciaioli, Anthropology and Sociology, School of Social Sciences, University of Western Australia and Prof. Yunita T. Winarno, Anthropology Department, Faculty of Social \& Politic, University of Indonesia, for the input and invitation as part of their panel.
} 


\section{Introduction}

The Orang Rimba has received prejudiced treatment from the state and society for centuries. Sandukt (2000) argued that there is a cultural process which causes the position and status of the Orang Rimba to always be below other ethnic groups in Jambi. Nevertheless, such marginalization process is not always accepted silently or without resistance. The Orang Rimba have developed their own ways to meet any action they face, or in James Scott's term 'public transcript'(Scott, 1992, p. 132 ), does not mean that the Orang Rimba were totally incapable of resistance. Under these new circumstances, there are indication that the Orang Rimba are 'fighting back', although in forms regarded as 'tacit rebellion' or in James Scott term, a 'hidden transcript' of the weapon of the weak (Scott, 1985).

This paper will explore many Orang Rimba's activities that pertain to their livelihoods. These livelihoods are not only regarded as activities to meet their needs but can also be viewed as a resistance of the conditions of deforestation that they face. With their forest home declining, they have few options for their lives. Their action can be interpreted as self-determination action. This action further strengthens their movement as a collective action as an initial social movement.

\section{Orang Rimba and Their Situation}

Orang Rimba or "Orang Kubu", or otherwise known as the "Suku Anak Dalam", is a term used to identify an ethnic group from Jambi, Sumatra. The majority of the Orang Rimba lives in Jambi Province and other areas in South Sumatra provinces. According to KKI Warsi study in 2010 there are 3,800 Orang Rimba people (KKI WARSI, 2008). Ecologically the Orang Rimba live in lowlands in Jambi Province which are distributed in three different geographical areas, namely western Jambi Province (around the eastern Trans-Sumatra Road), Bukit Duabelas National Park, and Bukit Tigapuluh National Park (along Riau and Jambi province border)(Sandbukt \& WARSI, 1998, p. 16).

The term "Orang Kubu" was first used by Van Dongen to refer to the primitive group of people that he encountered during a visit to Palembang. He called them "Rimba Ridan", or Orang Rimba along the Ridan River in Palembang. "Kubu" or "Ngubu" is defined by the Malays as a fort, and the term "Rimba" or forest is used to refer to people living in the forest (Dongen, 1910). The name "Orang Kubu" then developed into the standard terminology used to label these groups by the Malays. To the Jambi Malay community, Orang Rimba are known as an ethnic group that is synonymous to stupidity, poverty, primitiveness and geographic and cultural isolation (Muntholib, 1995; Prasetijo, 2005).

Orang Rimba went through a cultural marginalization process from the state Orang Rimba resettlements from the state were deemed successful only if they were willing to move to permanent settlements and change their entire lifestyles. Development models for "Isolated People Groups" such as the Orang Rimba have macro characteristics, material growth, and consumption levels that refer to the cultural majority in the area (the Jambi Malays) therefore its implementation can ignore local variations and interests of minority ethnic groups because they are not in line with the macro guidelines that the state applies. Government-directed development programs will lead to changes in these ethnic minorities, including Orang Rimba, into the 
dominant culture. This is apparent in popular development programs such as resettlement for remote communities. The New Order Government policy seems to become a legitimacy to construct Orang Rimba's ethnic identity under the shadow of dominant culture because they cannot follow the predetermined macro guidelines.

Ethnic culture marginalization process as it is occurring in the Orang Rimba is inseparable from what is referred to as the birth of national culture of this New Order era. National culture is a general concept and is usually present in the history of a modern nation, and is usually employed by the state to strengthen the unity of its diverse people who come from various cultural backgrounds. In its journey, the state strengthens its national cultural boundaries by using its political, economic and military power. This relates to the idea that efforts in forming a national culture are also an effort to search for ideological legitimacy to solidify the state's role in the eyes of its people (Foulcher, 1990). It is no surprise then that what shows is a symptom where the state uses all its political power and approach to "kill" local ethnic cultures, in which those ethnic cultures are deemed inconsistent with the national culture.

\section{Forest Management and Spatial Development in Jambi}

Data shows that forest degradation rates in Jambi are relatively high. For example, study results conducted by KKI Warsi ${ }^{2}$ through Landsat 8 images found that during 2012 to 2016 Jambi had lost 189,125 ha forest cover. Based on KKI Warsi's analysis from 2012, Jambi had 1,159,559 ha forest which by 2016 was reduced to 970,434 ha. According to KKI Warsi this loss of forest cover is due to human activities, dominated by conversing natural forest into industrial timber plantation concessions as well as legal or illegal land clearing for mining which extends into protected areas.

According to a survey conducted by KKI WARSI (2008), the Orang Rimba had to compete with all land suppression. And this spread widely across all groups existing in Jambi. What the Orang Rimba did to respond to the situation was different. Some groups moved to find remaining forest area in the good river basin, upstream of the Merangin River, Tabir River and Batang Bungo River. Some of them remained in the palm oil plantation owned by either the company or villagers. Some other groups, like Orang Rimba living in the area of Singkut, chose to move and stay at the temporary settlement provided by the state.

Some Orang Rimba groups living along the Sumatran Eastern Highway experienced a pitiful life. They kept moving to areas as far as Jambi City. Unlike other groups, these groups consisted of small groups that had a high mobility because they did not have land to cultivate. Unlike groups that still had land, although limited, some of the Orang Rimba living along the Sumatra Eastern Highway did not have land at all. Their choice was either to move to the settlement provided by the state or keep moving to find food. This is the group considered as troublemaker because they often steal villagers' crops or palm owned by the plantation and they sell them for the capital they need to move to other places. Orang Rimba living in the border area with the companies, including the palm company and Industrial Plantation Forest (HTI), as well as the Forest Concession (HPH) also experienced similar problems. Most forests in which they used to live and wander were now others' palm oils plantations and fields.

\footnotetext{
${ }^{2}$ http://www.warsi.or.id/content_news_showing.php?id=303
} 
KKI WARSI's report (2008) emphasized that land conflicts in Jambi occurred because the state did not acknowledge the traditional communities and always gave permission for the company to manage them as they wished. The company used violence to expel villagers. The frequent conflict was caused by the exploitation of forest area for purposes such as palm oil plantation, Industrial Plantation Forest, plantation, transmigration and mining. The development of Trans Sumatra Highway also contributed.

The development of the Trans Sumatra highway, resettlement, forest industry and large-scale palm oil plantations are four main causes of deforestation in Jambi. As mentioned, this affected the resources of local people who depended on forests. In addition, there had been an increase in population as a result of placement in Jambi, transmigration and plantations that had an effect on agricultural land and put pressure on the remaining forest (Boehmer, 1998). This situation exacerbated damage to the forest in Jambi. The existence of conversion forest deficits in many parts of Sumatra partly explains why large areas of production forest and limited production forest are now being allocated to plantation companies in Aceh, North Sumatra, Riau, Bengkulu, Jambi, South Sumatra and Lampung (Casson, 1999; Salmi, 2012)

In addition, land clearing is also done by communities for settlements and farmlands, although the areas are buffer to national park. Such is reported by KKI Warsi (2008) that in Merangin District, especially in Jangkat, areas within Kerinci Seblat National Park and its buffer has been cleared for coffee plantations. A large capital and effective group work is needed to clear land in these areas. Furthermore, the presence of the mining industry also contributes to decreasing forest areas in Jambi.

With dwindling forests, conflicts over natural resources are inevitable. Study conducted by Taufik Yahya (2013) from Jambi University's Faculty of Law shows that natural resources conflicts in Jambi have increased dramatically in both types and frequencies. There are 29 land conflict cases in which several have been resolved by the Jambi Provincial Government as facilitator. Several conflicts are between big companies and indigenous peoples who have long lived in the area. Land control exerted by the state and private sector has led to indigenous peoples to lose their lands because the state does not recognize the indigenous peoples and their lands. Yahya (2013) also noted about conflicts such as those between PT Asiatic Persada against the Suku Anak Dalam Batin 9 in Muaro Jambi and Batanghari Districts and the case between PT Sari Aditya Loka (SAL) against Orang Rimba in Air Hitam demonstrate such conditions also.

Jambi Province spatial plan provides no area for indigenous peoples to develop. There are a number of indigenous peoples in Jambi, such as Orang Rimba, Suku Anak Dalam Batin Sembilan, the Bajau people, and other groups. According to the Ministry of Social Affairs, there are approximately 235,282 people from minority groups out of Jambi's 2 million inhabitants, as of 2000 (Ministry of Social Affairs, 2000). The number is not much change from right now. In other words, indigenous peoples comprise approximately 10 percent of Jambi's population.

With such small numbers, it can be understood that these people are viewed as minorities as opposed to other groups in Jambi. Jambi's spatial plan regulation, or Jambi Province Regulation No. 10 of 2013 concerning Spatial Plan for Jambi Province 2013-2033 does not provide living spaces for these indigenous peoples' groups. The lands in Jambi have been entirely distributed for agriculture for local development, 
settlements and local development, and protected areas for natural resources conservation.

Looking at KKI Warsi's 2008 Bioregion Survey analysis (2008), the Orang Rimba are clearly marginalized. Their rights to living and land go unappreciated by the state. Their lands were handed over to individually or company-owned palm oil plantation concessions, industrial timber plantations, and settlements. Indeed, they have been marginalized from their own land. From the cases shared by KKI Warsi, the lives of the Orang Rimba living in the Trans-Sumatra roads are disheartening. They were displaced from their own lands that now belong to other parties. The Orang Rimba that still own land lives along rivers, which must be protected by companies as riverbank buffers. They too have lost the sources of their subsistence due to the loss of forests.

\section{Deforestation and Its impacted to Orang Rimba in Jambi}

In 2016, local newspaper releases news regarding Orang Rimba's shelter burned by a palm oil company's security staff. The Orang Rimba were accused of stealing loose palm oil fruits and squatting on company grounds ${ }^{3}$. This is not the only case conflict between Orang Rimba and palm oil companies. Rahman (2008) and KKI Warsi (2014) estimated that since 2000 there have been 21 conflicts between Orang Rimba, whether among the Orang Rimba or against other groups. As many as 14 Orang Rimba have died in relation to these cases. Detailed cases below:

\section{The Conflict Case that Caused Death for Orang Rimba}

\begin{tabular}{|c|c|c|c|c|}
\hline No & Case & Year & $\begin{array}{l}\text { Victim Died in } \\
\text { person }\end{array}$ & Resolution \\
\hline $\mathbf{1}$ & $\begin{array}{l}\text { Orang Rimba Murder case in } \\
\text { Sungai Ruan Village, } \\
\text { Batanghari District }\end{array}$ & 1997 & 2 & $\begin{array}{l}\text { No legal process, resolved } \\
\text { customarily }\end{array}$ \\
\hline 2 & $\begin{array}{l}\text { Murder and Robbery of Orang } \\
\text { Rimba Nalo group in } \\
\text { Merangin District }\end{array}$ & 2000 & 7 & $\begin{array}{l}\text { Legally settled three of the } \\
\text { perpetrators were sentenced to death }\end{array}$ \\
\hline 3. & $\begin{array}{l}\text { The Orang Rimba were shot } \\
\text { in the small Kejasung area at } \\
\text { Batanghari District }\end{array}$ & 2001 & 1 & No legal process \\
\hline 4 & $\begin{array}{l}\text { Orang Rimba in the } \\
\text { Pamenang sub-district was } \\
\text { shot in Merangin District }\end{array}$ & 2007 & 1 & $\begin{array}{l}\text { No legal process, resolved } \\
\text { customarily }\end{array}$ \\
\hline 5 & $\begin{array}{l}\text { Orang Rimba Nungkai group } \\
\text { was attacked by villagers of } \\
\text { Bunga Atoi, Merangin District }\end{array}$ & 2011 & 1 & $\begin{array}{l}\text { No legal process, resolved } \\
\text { customarily }\end{array}$ \\
\hline 6 & $\begin{array}{l}\text { Orang Rimba murder in } \\
\text { Harun's group at Pemenang } \\
\text { Transmigratian area, } \\
\text { Merangin District }\end{array}$ & 2011 & 2 & $\begin{array}{l}\text { No legal process, resolved } \\
\text { customarily }\end{array}$ \\
\hline
\end{tabular}

Source : KKI Warsi (2014)

\footnotetext{
${ }^{3}$ http://www.mongabay.co.id/2016/06/04/malangnya-nasib-orang-rimba-di-kebun-sawit-perusahaanternama-ini/
} 
With these conditions, the Orang Rimba must find a way to deal with their lives, especially with their livelihoods. For them, the forest is not only a source of livelihoods but also a source for their traditions and culture. Many of their traditions take root in the forest, so it can be said that their forest is their cultural identity.

Sandbukt (1988) categorized the Orang Rimba as an economically-based huntergatherer group. Hunting provides the basis for their subsistence for their primary diet. They also farm to a limited extent for their subsistence. Moreover, gathering is an activity conducted as part of their traditional economic network at the time. The Orang Rimba people collect forest resources to sell to the jenang and waris as middlemen, who will then sell the goods in Jambi. The products harvested are largely non-timber forest products, such as rattan, dragon blood (jernang), ironwood, and other products. During the colonial times, the Dutch introduced production plants as parts of controlling production centers in Sumatra. The colonial introduced rubber trees to the Jambi Sultanate and imposed production tax on rubber. Rubber production was then introduced by the sultanate to the people of Jambi. Orang Rimba were then exposed to rubber as an industrial crop.

In this context, they are bound by an economic system that places them in the forefront of the world's capitalistic economy. Their livelihoods are part of the peripheral of a traditional economy system supporting the central economy. Several Orang Rimba groups in Bukit Duabelas National Park still maintain their subsistence activities of hunting, gathering, farming and planting rubber (KKI WARSI, 2008; Prasetijo, 2005). In the following times, the Orang Rimba were forced by the Malays to clear the forest to plant rubber and sell the product to the owners.

There have been many changes concerning Orang Rimba's lives since the 1980s. Settlement and road constructions have cleared the once closed off living spaces of the Orang Rimba. Logging companies clear their lands into forest areas, and boundaries between forests and settlements are cleared also. All these affected the Orang Rimba's livelihoods. They became exposed to other livelihoods from outsiders. Many outsiders forced their way, clearing lands for farms, rubber plantations and palm oil well into Orang Rimba's territory (see Ø. Sandbukt, 2000).

For their livelihoods, the Orang Rimba mostly rely on rubber plantations, farming, and providing services such as boar hunting in palm oil plantations, driving motorcycle taxis or ojek, and working in other non-formal sectors. Report from KKI Warsi (2008) also noted with the disappearing of the forest, so do opportunities for them to work for subsistence. This is even more evident for the Orang Rimba groups living along roads. They have no other option. As opposed to the Orang Rimba groups living in Bukit Duabelas National Park that still have the option to plant rubber and harvest non-timber forest products in the park, the former has no other choice.

The impact on the Orang Rimba is the loss of their livelihood. When compared with a few years ago where the dense forest, they say that it is now very difficult to find the animals in the forest. Wild animals such as deer are very rare they get. Similarly, the wild boar. Usually once to get a wild boar often within a few days or a week two times for sure they will get it. But now very difficult to obtain on a regular basis.

Likewise, the pattern of subsistence that they did. If once they could farm for two years and then they store the results, but now it is very difficult to do so. They are difficult to open the field because the limitation of land. Forest has narrowed. And they have to compete with others. To get staple foods such as rice they have to buy in the market in villages nearby. All they can do now is to cultivate their own land with rubber 
trees, so that the sap can be taken and sold. Rubber for Orang Rimba is a sensible choice because they understand how to care for and have a clear channel to sale. Choice of living in the forest they think now becoming more and more limited when compared to the time it used to be.

Several Orang Rimba finds it difficult for them to make a living in the forest. Some non-timber forest products commodities are now no longer salable. Such as jernang sap, resin, and some other commodities, although it is mostly found in the forest, but cannot be sold like the past. Similarly, the cult wild honey in sialang tree, to search for it should go deep into the forest. They feel the fruit seasons in the forest has also changed. If before, season fruits in the forest can be harvested for several months during the year, but is now just a month or no more than once a year only.

Another way that can be done by Orang Rimba to address their situation is to do a find and ask for a job to someone else. They work irregular jobs and do what they can do. However, discrimination makes it difficult to get a job. The stigma that they are thieves and stubborn has strongly stuck. The work they do now is mostly paid work but it is an uncertain income. For example, hunting wildboar on the palm oil plantation. The company considers the wildboar an infestation and only the Orang Rimba knows its detailed behavior. However, it has started to become extinct since the 2000s. It takes one week to hunt a boar.

This issue also invites a deeper social problem. There are many Orang Rimba leaving their homes and leaving their area not just for hunting, but also for begging on the street and in the settlement (Yulis, 2010). They even go as far as the capital of Jambi. Those who beg always open a camp in the plantation near the settlement. They live in the camp for a few days, and even weeks or months, then they move again because their behavior causes them to be expelled by the villagers who are not comfortable seeing them (Sukmareni, 2007). In addition, they also commit crime. In my research in 2005 (Prasetijo, 2005), what they often do is steal a bunch of palm from the plantation and then sell it to the toke. This is high-risk job because it will provoke violence from the officials and the plantation owner. One thing they agree on is that they have no chance to improve their condition. They have to accept the same conditions that their ancestors also experienced.

\section{Orang Rimba's Livehoods as Tacit Resistance}

From the result of the research I that have done (Prasetijo, 2014), Orang Rimba's livelihood options are limited due to their increasingly restricted living space and lack of resources. If asked about their work, they will reply that they take on any type of work to provide for their needs. In the past, they relied on farming and hunting and gathering in the forest, but this option is no longer available to them. There were a number of times when the Orang Rimba attempted to clear land in company community lands that were once their land, but this lead to conflicts.

For the Orang Rimba living outside of Bukit Duabelas National Park, their livelihoods rely on activities other than farming and hunting that they would normally do (see KKI WARSI, 2008). They also resort to the following activities: stealing palm oil fruit bunches in plantations to sell, hunting boars to sell to companies, begging in Jambi City or other big cities asking for the public for money for food, or even stealing, blockade roads, and claiming company lands to occupy as part their ancestor's land. In other case, Orang Rimba in Bukit Duabelas also open the forest for hompongon. 
Hompongan is actually lined rubber plantation made by Orang Rimba that is useful to be the boundary between the forest boundary and the plantation owned by outsiders. This action has made the outsiders can continue to open the forest for the palm oil plantation. In view of outsiders, the action has done by Orang Rimba was illegal and emerge the conflict tension between them and Orang Rimba.

Cases such as roadblock is the common action taken by the Orang Rimba, as occurred to some logging and plantation companies (WARSI, 2011) located around the Bukit 30 National Park. PT. WKS is a subsidiary of Sinar Mas Group, a palm oil, and paper pulp and forest industry group holding company. It is one of the biggest paper pulp companies in Indonesia with hundreds of companies throughout the country. The conflicts occurred in April 2011. The case of the Orang Rimba blocking the entrance to the company site represents the culmination of their anger and resentment towards the company that was not willing to negotiate and solve the problems ${ }^{4}$.

In addition, cases of stealing led to conflicts between the Orang Rimba and outsiders. The conflicts with the villagers are mostly caused by thefts committed by Orang Rimba. The theft cases then cause various problems for not only the villagers, but also other parties. Some of the thefts are usually related to those of agricultural products from the rural communities, TBS or Tandan Buah Segar (Palm Fruit Bunches) from palm oil plantations and timber or illegal logging within the protected forest areas owned by the state or company. As a result, these theft cases lead to a feeling of suspicion and resentment of outsiders towards Orang Rimba.

In certain cases, thefts committed by Orang Rimba spark outrage and violence against them. The main reason for the thefts committed by Orang Rimba is that, according to them, they have no more food and forest for living. The thefts then spark outrage among rural communities. Many theft cases are associated with the theft of natural resources for food or processed food. They sometimes take items without paying, as in an incident in Bukitbungkul village, Pamenang sub-district ${ }^{5}$.

However, the Orang Rimba people admit to these actions. They said that they had serious trouble finding food because their land was gone. In addition, the usual foods they get from the forest, such as root crops, have also been difficult to obtain due to the disappearance of the forests where they used to wander. The Orang Rimba do understand that the theft they committed is wrong. Nevertheless, they have to do it since there is no available food to eat while working to earn money is difficult because no one wants to hire them.

Finding in my doctoral research (Prasetijo, 2014), another explanation to stealing is their numerous and urgent needs, all the while they could not get jobs. In the past, they did not need to buy as their subsistence are provided by their farms, or they were able to find food in the forest. Today they must earn money to purchase their needs.

And then there was a time when they sold their rubber lands to meet the needs of their daily life and the desire to buy other goods. The things that once regarded as a luxury now frequently appear in front of them. Motorcycles, for instance. In the past, they could not imagine buying a motorcycle. However by selling two or three acres of land, they can buy. The need for such things is very confusing for them because they see them used by the villagers every day. As a consequence, they are interested in

\footnotetext{
${ }^{4}$ Conflict between the Orang Rimba and corporate at the Bukit 30 National Park. Source: Report of KKI WARSI, One Conflict with one Thousand of Interest in the South Part of The Bukit 30 National Park (TNBT), April 2011

${ }^{5}$ Source: Kubu jarah Toko Manisan, Jambi Ekpres, 29/01/2005
} 
buying them. Mobile phones, motorcycles, televisions and radios are no longer luxuries for them but are considered as day-to-day needs. The Orang Rimba living around Bukit Duabelas National Park usually also sell their remaining land from the land allocated by the Ministry of Social Affairs or companies, but then there would be no more land. The only thing left to do is steal to meet their needs (see Prasetijo, 2005).

The next case is land acquisition. The land acquisition or land claim is a sensitive issue because of the complex land problems in Jambi. Many cases of land disputes between the Orang Rimba and other parties are related to land claims made unilaterally by Orang Rimba. In fact, the issue of land claims by Orang Rimba is not a stand-alone issue but the impact of the issues of land takeover by the state, company and villagers upon Orang Rimba's lands or forests. Orang Rimba claimed the palm oil land owned by the villagers. This problem became more complicated since the villagers insisted that the land did not belong to the Orang Rimba but it was a forest that had long been abandoned. The villagers saw that after turning it into a palm oil plantation, the land was then suddenly claimed by Orang Rimba. This case was eventually resolved when the state assisted in the mediation and attempted to settle this incident peacefully by asking the farmers (villagers) to give a sum of money as indemnity to the Orang Rimba. Similar cases also occurred elsewhere ${ }^{6}$.

Some of Orang Rimba's claims on the company's lands are successful, e.g. a claim on the customary land located in Air Panas area delivered to PT. SAL. As a consequence, the company is very careful in approaching them. Nevertheless, the problem and its impact is different when it is associated with the village community. The cases of land claims are often found in the Orang Rimba groups existing in southern Jambi where the forests have been fully converted to plantations and transmigration settlements. The remaining lands are subsequently converted by the villagers to rubber plantations.

Thus, after all the cases from the view of the state and other parties was regarded is criminal action. The Orang Rimba's actions, including road blocking, demonstration, theft and land occupation or land claim, were responses to a service of events and administrative decisions related to land acquisition by the state and companies for establishing settlements, roads and other infrastructures that cause the Orang Rimba to lose their lands. While, the direct effect of forest clearings was acute deforestation, the social implications were more severe as the tribe lost their living place and the gathering area for looking for food. Forest clearing for whatever purpose disrupt the cultural ecology balance of the Orang Rimba, as the forest serves not only as a place to find food, but is also a cultural symbol of the Orang Rimba.

Social responses, expressed in the act of theft, are acts that raise complicated social implication potential of parallel conflicts between the Orang Rimba and the villagers. The cases of stealing and other activities can be understood as being culturally expressed due to how they relate to the relationship with the ethnic majority, Jambi's Malays.

In many cases, incidences started with trivial action, which later leads to factional disputes and fights. It is undeniable that there are still negative stereotypes and stigma among the Jambi people about the Orang Rimba, which the Orang Rimba 'accepted' in

\footnotetext{
${ }^{6}$ Source: Edition of Saturday, 02 June 2012 09:46, SAD Bentrok dengan Warga
} 
silence, but to regard passivity as ignorance and primitiveness was the main point of contention among the Orang Rimba.

\section{NGO's Role and Social Platform for Social Resistance}

NGOs play a significant role in Orang Rimba's struggle. Orang Rimba actions against the injustice they encountered are related to other issues that have emerged in Jambi and are in line with the change of Indonesia's political structural, which has shifted to transparency and the decentralization of power away from central state to provincial and regency. Such a situation invites chaos that causes political instability, which in turn causes a change of local political structure and invites new political strata in the region.

In my opinion, the Orang Rimba have always been in a disadvantaged position within the social structure of modern society and this has made them helpless in confronting the injustice they are experiencing. They are in an underdog position because they do not have the power to elevate their role within Jambi society and therefore do not have strong social status within the Jambi social structure.

The most discussed and correlated issues concern the existence of the Orang Rimba is loss of forest. Uncontrolled development programs and palm plantation expansion programs have caused a fast deforestation in Jambi, affecting its indigenous minority, including the Orang Rimba. Conflict does not only arise between the Orang Rimba and the state and companies, but also among the ethnic majority in Jambi (the Malay). Access to natural resources have been raised as the main issues. On the other hand - the Orang Rimba's problems accentuated by the issue of violation of human rights. And lack of concern by the state in addressing these rights.

Non-Governmental Organizations or NGO have emerged as a result of a more active and well-organized civil society in Indonesia. The NGOs have increasingly thrived in numbers and capacity as Indonesian politics became more open since the Reformation era of 1998, which has allowed people to gather and to express their voices freely. The involvement of NGOs during this period provided the social and political platform to strengthen the capability of engagement with the bureaucracy and at the same time, eased communication with of the state apparatus.

If in the past it had been sporadic and immeasurable, NGOs have included Orang Rimba's struggle as indigenous peoples into an agenda that has gained public attention. NGOs involvement began with KKI Warsi's involvement in the 1999 Indigenous Peoples' Congress where KKI Warsi placed the Orang Rimba as indigenous people and no longer as isolated people as the state regarded them. I believe that NGOs presents Orang Rimba's position as they are, as a statement of self-determination. With the development programs implemented, Orang Rimba obtained recognition from the state and foreign stakeholders. Orang Rimba can talk to other tribes as equals and this is an extraordinary feat by NGOs. In this context, NGOs helped Orang Rimba's 'tacit resistance" to become more directed and measurable, and more weighted when in a holding counter discussion with the state and companies, so that their activities are no longer criminal. 


\section{Discussion}

We can understand that what the Orang Rimba are doing is trying to resist the injustice that they face. With the disappearing forest resources and the marginalization faced, the uneven abilities compared to other parties, the Orang Rimba cannot compete with these other groups.

They have become part of the global economic chain and dependent on the market. In the past they depended on forest resources, but when the market now only views forest merely as lands, with sole ownership and management entities, the Orang Rimba cannot do anything. They are in the peripheries, the lowest of the economy chain that functions to support investors.

Orang Rimba livelihoods that based on in my opinion can be regarded as 'tacit resistance' or, to use James Scott's term, a 'hidden transcript' of the weapons of the weak (Scott, 1985). They use a variety of ways to make a living, both economic and sociocultural. The Orang Rimba has received unfair treatment from the state and society for centuries. There is a cultural process which causes the position and status of the Orang Rimba to always be below other ethnic groups in Jambi. Nevertheless, such marginalization process is not always accepted silently or without resistance. The Orang Rimba have developed their own ways to meet any action they face, or in James Scott's term 'public transcript' (Scott, 1992), does not mean that the Orang Rimba were totally incapable of resistance. Under these new circumstances, Orang Rimba are 'fighting back', although in forms regarded as 'tacit rebellion' or in James Scott term, a 'hidden transcript' of the weapon of the weak (Scott, 1985).

Their action is related to their self-determination as Orang Rimba. Orang Rimba have their own ways of responding to any external repression that they encounter. It can be said that the Orang Rimba's ways of responding to changes are varied. Regarding the aforementioned cases, it seems there are some differences. However, those actions can be interpreted as a move appropriate description is 'everyday resistance', a concept introduced by James Scott (1985, p. 225 ) to refer to the form of resistance that culturally expressed in their daily live. 


\section{Reference:}

Boehmer, K. 1998. Analisis Awal Tata Ruang dan Lingkungan Hidup Jambi. Retrieved from Jambi:

Casson, A. 1999. The Hesitant Boom: Indonesia's palm oil sub-sector in an era of economic crisis and political change, Program on the Underlying Causes of Deforestation. Retrieved from Bogor, Indonesia:

Dongen, v. 1910. De Koeboes in de OnderafdeelingKoeboestreken der Residentie Palembang (trans. Orang Kubu in Onderafdeling Palembang) (Museum Negeri Jambi, Trans.): Bijdragen tot de Taal,-Land-en Volkenkunde van NederlandschIndie

Foulcher, K. 1990. The Construction of an Indonesian National Culture: Patterns of Hegemony and Resistance. In A. Budiman (Ed.), State and Civil Society in Indonesia (pp. 301-321). Clayton Victoria: Monash University Centre of Southeast Asian Studies.

Jambi Ekspress. 2005, 29 January. Kubu jarah Toko Manisan. Jambi Ekpres.

KKI WARSI. 2008. Survey Bio-Regional Jambi. Retrieved from Jambi:

Ministry of Social Affairs. 2000. Panduan Teknis Pemberdayaan Lingkungan Sosial Komunitas Adat Terpencil. Jakarta: Direktorat Bina KAT - Ministry of Social Affairs.

Muntholib. 1995. Orang Rimbo: Kajian Struktural - Fungsional Masyarakat Terasing di Makekal, Propinsi Jambi. (PhD Thesis), Universitas Padjajaran, Bandung.

Prasetijo, A. 2005. Kehidupan Orang Kubu dibawah pengaruh Orang Melayu. (Master Thesis), Universitas Indonesia, Jakarta.

Prasetijo, A. 2014. Alternative Strategies And Actions nAgainst Hegemony By Orang Rimba of Jambi, Sumatra (Ph.D), Universiti Sains Malaysia, Penang, Malaysia.

Rahman, A. 2008. Konflik Sebagai Simbol Perlawanan Terhadap Korporasi dan Kebijakan (Melihat Konflik di Tengah Komunitas Orang Rimba). Paper presented at the Workshop Ancaman Etno-Ekologi Orang Rimba Dari Hegomoni Kapitalis dan Strategi Penyelamatannya, Jambi.

Salmi, M. 2012. Jambi Punya Perkebunan Sawit 515.300 hektare. Retrieved from http://jambi.antaranews.com/berita/296672/jambi-punya-perkebunan-sawit515300-hektare

Sandbukt, \& WARSI. 1998. Orang Rimba: Needs Assessment for Resource Security and Development: The World Bank and the Government of Indonesia. Retrieved from Jambi:

Sandbukt, Ø. 1988. Resource Constraints and Relations of Appropriation among tropical Forest Foragers. the Case of the Sumatran Kubu. Research in Economic Anthropology, 10, 117-156.

Sandbukt, Ø. 2000. Deforestation and the people of the forest: the Orang Rimba or Kubu of Sumatra. Indigenous affairs(2), 39-47.

Scott, J. 1985. Weapons of the Weak: Everyday Forms of Peasant Resistance: Yale University Press.

Scott, J. 1992. Domination and the Arts of Resistance: Hidden Transcripts: Yale University Press.

Sukmareni. 2007. Mereka Tercerabut dari Akarnya. Alam Sumatra, 2/Fifth Year 2007. 
Endogami: Jurnal Ilmiah Kajian Antropologi

E-ISSN : 2599-1078

WARSI, K. 2011. One Conflict with one Thousand of Interest in the South Part of The Bukit 30 National Park (TNBT). Retrieved from Jambi:

Yahya, T. 2013. Resolusi Konflik dalam Pengelolaan Sumber Daya Alam: Studi di Kabupaten Batanghari. Inovatif FH Unja, 16 No 2

Yulis, H. 2010. Orang Rimba Mengemis. Retrieved from http://www.jambiindependent.co.id/jio/index.php?option=com_content $\&$ view=article \&id=10620: orang-rimba-mengemis \&catid=3:jambitimur \&Itemid $=5$ 